\title{
A Role for Transcriptional Repressor Methyl-CpG-Binding Protein 2 and Plasticity-Related Gene Serum- and Glucocorticoid-Inducible Kinase 1 in the Induction of Inflammatory Pain States
}

\author{
Sandrine M. Géranton, Cruz Morenilla-Palao, and Stephen P. Hunt \\ Department of Anatomy and Developmental Biology and London Pain Consortium, UCL, London WC1E 6BT, United Kingdom
}

\begin{abstract}
Activity-dependent changes in neurons of the rat superficial dorsal horn are crucial for the induction and maintenance of neuropathic and inflammatory pain states. To identify the molecular mechanisms underlying this sensitization of superficial dorsal horn neurons, we undertook a genome-wide microarray profiling of dorsal horn gene transcripts at various times after induction of peripheral inflammation of the rat ankle joint. At early time points, upregulation of gene expression dominated, but by $7 \mathrm{~d}$, downregulation was predominant. Two to $24 \mathrm{~h}$ after inflammation, we identified a small number of highly upregulated transcripts previously shown to be repressed by the Methyl-CpG-binding protein 2 (MeCP2), including serum- and glucocorticoid-inducible kinase (SGK1) and FK 506 binding protein 5, genes known to be important in experience-dependent plasticity. A decrease in expression of SIN3A, a corepressor in the MeCP2 silencing complex, was also found after inflammation. Phosphorylation of MeCP2 regulates activity-dependent gene transcription, and crucially we found that $\mathrm{MeCP} 2$ was phosphorylated in lamina I projection neurons $1 \mathrm{~h}$ after induction of peripheral inflammation. Lamina I projection neurons have been shown to be essential for the development of most pain states. SGK1 protein was also localized, in part, to lamina I projection neurons, and its expression in the superficial dorsal horn increased after inflammation. Furthermore, antisense knock-down of SGK1 delayed the onset of inflammatory hyperalgesia by $24 \mathrm{~h}$ at least. Our results uncover an unexpected complexity in the regulation of gene expression, including the modulation of transcriptional repression, that accompanies development and maintenance of an inflammatory pain state.
\end{abstract}

Key words: inflammation; lamina I; SGK1; MeCP2; transcriptional repression; antisense technology.

\section{Introduction}

Peripheral inflammation of the skin or joints leads to enhanced pain sensitivity, which follows the establishment of long-term changes in synaptic efficacy between primary afferents and dorsal horn neurons and activation of ascending projections to the brainstem that engage descending pathways terminating within the dorsal horn (Woolf, 1983; Hunt and Mantyh, 2001; Khasabov et al., 2002; Suzuki et al., 2002). The key dorsal horn neurons in this process have been shown to be the lamina I projection neurons that express the NK1 (substance P-preferring) receptor, are primarily nociceptive (Torsney and MacDermott, 2006) and project to the brainstem (Todd, 2002; Todd et al., 2002). Selective ablation of these neurons with saporin-substance P (SP-SAP)

Received Feb. 5, 2007; revised April 24, 2007; accepted April 30, 2007.

This work was supported by Wellcome Trust Research Grant 065374. We thank Anne Sheasby, Amy Fisher, and Yuk Wong for their technical assistance; Caroline Johnston for her help with R programming; and Zhaolan (Joe) Zhou and Michael Greenberg for providing the antibody against phospho-MeCP2.

Correspondence should be addressed to Sandrine M. Géranton, Department of Anatomy and Developmental Biology, UCL, Medawar Building, London WC1E 6BT, UK. E-mail: ucgasmg@ucl.ac.uk.

DOI:10.1523/JNEUROSCI.1306-07.2007

Copyright $\odot 2007$ Society for Neuroscience $\quad$ 0270-6474/07/276163-11\$15.00/0 conjugates prevents the induction and maintenance of inflammatory and neuropathic pain states implying that these neurons are essential for the initiation and perhaps maintenance of many pain conditions (Nichols et al., 1999).

Recent studies have identified two populations of lamina I/NK1-positive neurons that support long-term potentiation (LTP), a form of central sensitization, after either low- or highfrequency high-threshold stimulation and proposed that this "synaptic amplification" contributes significantly to the appearance of increased pain sensitivity (Ikeda et al., 2003, 2006). It has also been shown that, at least in deeper dorsal horn neurons, the appearance of LTP-like events after high-threshold stimulation of primary afferents is critically dependant on intact lamina I projection neurons, and LTP is not induced if these lamina I neurons have been ablated with SP-SAP conjugates (Rygh et al., 2006). Crucially, noxious stimulation of the hindpaw was also shown to generate LTP within lamina I, suggesting that LTP-like changes in the dorsal horn may be a necessary requirement for the generation of pain states (Ikeda et al., 2006; Klein et al., 2006). This compelling correlation is also supported by evidence from numerous molecular and pharmacological studies demonstrating that reduced central sensitization in the dorsal horn generally 
equates with attenuated pain behavior (Millan, 1999; Ji et al., 2003; Garry and Fleetwood-Walker, 2004).

It is now well established that long-term changes in synaptic efficacy requires macromolecular synthesis (Bailey et al., 1996; Pittenger and Kandel, 1998; Martin et al., 2000). Therefore, an analysis of changes in gene expression in lamina I neurons and more generally in dorsal horn neurons could lead to the identification of novel molecules important for the induction and maintenance of pain states, many of which have proved difficult to manage clinically (Bennett et al., 2007).

In this study, we analyzed dorsal horn gene expression after sensitization of joint afferents that have been shown to preferentially terminate within lamina I and activate lamina I-NKIpositive neurons (Neugebauer et al., 1994; Doyle and Hunt, 1999). We report that some early changes in gene expression that support pain behavior are associated with the activation of the gene repressor Methyl-CpG-binding protein 2 (MeCP2), a gene previously identified as mutated in Rett disease and implicated in the development of synaptic plasticity in the human brain.

\section{Materials and Methods}

Animal preparation. All procedures complied with the United Kingdom Animals (Scientific Procedures) Act 1986. Experiments were performed on male Sprague Dawley rats (200-230 g body weight at the beginning of each experiment) from the colony at UCL. Animals were kept in their home cage at $21^{\circ} \mathrm{C}$ and $55 \%$ relative humidity with a $12 \mathrm{~h}$ light/dark cycle (lights on at 8:00 A.M.) and were fed food and water ad libitum. All efforts were made to minimize animal suffering and to reduce the number of animals used. Inflammation was induced by injection of Complete Freund's Adjuvant (CFA; $10 \mu \mathrm{l}$ ) (Sigma, Poole, UK) in the left ankle joint, under halothane anesthesia induced in a closed chamber delivering $5 \%$ halothane combined with $100 \% \mathrm{O}_{2}$ at $2 \mathrm{~L} / \mathrm{min}$ and maintained during the injection by the delivery (via a face mask) of $1.5-2 \%$ halothane combined with $100 \% \mathrm{O}_{2}(1 \mathrm{~L} / \mathrm{min})$. The needle entered the ankle joint from the anterior and lateral positions, with the ankle kept in plantaflexion to open the joint. Sham treatment consisted of anesthetizing the animals and breaking the joint capsule with a needle as for an injection.

Behavioral assay. To assess the pain after the development of inflammation, response to a mechanical stimulus was measured with the Automatic Von Frey apparatus or the Analgesy-Meter (Randall-Selitto test), both from Ugo-Basile (Comerio, Italy). Pain threshold was only assessed with one test, according to the experiment. In both cases, animals were left to habituate to the experimental room in their home cage for $15 \mathrm{~min}$ before the beginning of each testing session. Each animal was tested four times with a resting time of $10 \mathrm{~min}$ between each measurement. For the automatic Von Frey, the ramp was set for the maximum stimulus ( $50 \mathrm{~g}$ ) to be reached in $20 \mathrm{~s}$. For the Randall-Selitto test, no extra discs were added to the basic settings of the apparatus, and paw withdrawal (not vocalization) was taken as a measure of pain threshold.

Tissue collection and RNA preparation. For tissue collection, animals were terminally anesthetized with $\mathrm{CO}_{2}$ at $2 \mathrm{~h}, 6 \mathrm{~h}, 24 \mathrm{~h}$, or $7 \mathrm{~d}$ after sham surgery or CFA injections, or naive. The spinal cord segment corresponding to the lumbar area was rapidly removed, and the ipsilateral dorsal horn quadrant L4-L6 was dissected out and frozen on dry ice. Samples were then stored at $-80^{\circ} \mathrm{C}$ until further processing. Total RNA was extracted from homogenized dorsal quadrant pooled from distinct animals [three for the microarray study and two for the real time quantitative PCR (RT-qPCR) experiments] using an acid phenol extraction method (TRIzol reagent, RNeasy mini-columns; Qiagen, Crawley, UK). RNA concentration was calculated from the $A_{260}$ value given by the Nanodrop (Labtech International, Ringmer, UK), and the quality of the samples was assessed with the 2100 Bioanalyser (Agilent Technologies, Santa Clara, CA). All samples showing satisfactory quality were used for RT-qPCR or the preparation of probes according to the Affymetrix protocol (see GeneChip Expression Analysis Technical Manual, available at Affymetrix website). Probes were hybridized onto Affymetrix Rat Genome 2302.0 GeneChip (31042 probe sets), with three biological replicates for each of
Table 1. Sequences of primers for RT-qPCR

\begin{tabular}{lll}
\hline Gene & & Primer sequence \\
\hline$\beta$-Actin & $\mathrm{F}$ & $5^{\prime}$-AGATTACTGCCCTGGCTCCTA-3' \\
PDYN & $\mathrm{R}$ & $5^{\prime}$-AGGATAGAGCCACCAATCCAC-3' \\
& $\mathrm{F}$ & $5^{\prime}$-CACCTGATCAGCCAGAAGC-3' \\
SGK1 & $\mathrm{R}$ & $5^{\prime}$-GATCACAAGGAGGCAAGCTG-3' \\
& $\mathrm{F}$ & $5^{\prime}$-GGGCTGTCTGGTATGAGATGC-3' \\
FKBP5 & $\mathrm{R}$ & $5^{\prime}$-GTGCCTTGCTGAGTGGTG-3' \\
& $\mathrm{F}$ & $5^{\prime}$-CACCCTGAGCCTGGAGAGAG-3' \\
SULT1A1 & $\mathrm{R}$ & $5^{\prime}$-GTGTCGCATTACTCGCAGAG-3' \\
& $\mathrm{F}$ & $5^{\prime}$-CCGAGGAGACTGTGATTC-3' \\
SIN3A & $\mathrm{R}$ & $5^{\prime}$-GCATAGTGGGCATCAAAGC-3' \\
& $\mathrm{F}$ & $5^{\prime}$-CAGCATATTGTCAGCGACGAG-3' \\
UbE3A & $\mathrm{R}$ & $5^{\prime}$-GTGGCTCGTTGTTGTTTCC-3' \\
& $\mathrm{F}$ & $5^{\prime}$-CCTTCTTGTAGTAGTTGAGGCAGAG-3' \\
& $\mathrm{R}$ & $5^{\prime}$-TCACATTACCTTATCACAATATGGAACG-3'
\end{tabular}

When possible, primers targeted the area of the gene sequence used by Affymetrix to design the probes hybridized onto the microarray. F, Forward primes; R, reverse primes.

the five time points of the study (total of 45 animals used for the microarray study).

Microarray analysis. Microarrays were scanned with GeneChip Scanner 3000 (Affymetrix) and DAT files (raw image data) were converted into CEL files (probe levels data) with GeneChip Operating Software (Affymetrix). CEL files were analyzed under R, a language and environment for statistical computing, using Bioconductor, an open source software for bioinformatics (Gentleman et al., 2004). After quality control assessment, Limma statistical testing (Smyth, 2004) was applied. We generated four lists of genes by ranking genes by $p$ value for each of the four comparisons: naive versus $2 \mathrm{~h}, 6 \mathrm{~h}, 24 \mathrm{~h}$, and $7 \mathrm{~d}$. We selected for additional study the genes of the top 100 of each list, which had a foldchange compared with naive $>1.3$ (see Results for more details). Annotated genes were classified in functional and biological families using GenMAPP (Gladstone Institutes, San Francisco, CA) (Dahlquist et al., 2002) and MAPPfinder (Gladstone Institutes) (Doniger et al., 2003).

$R T$ reverse transcriptase PCR assay. Tissue preparation and RNA extraction were as described above. RNA samples were treated with DNase I (Qiagen). Equal amounts ( $3 \mu \mathrm{g})$ of total RNA were reversed transcribed using random nonamers (Sigma), oligo $(\mathrm{dT})_{15}$ primers (Promega, Madison, WI), and Superscript TM III RT (Invitrogen, Carlsbad, CA), $1 \mathrm{~h}$ at $50^{\circ} \mathrm{C}$ in a total reaction volume of $20 \mu \mathrm{l}$. cDNAs were immediately quantified by RT PCR or kept at $-20^{\circ} \mathrm{C}$ until additional experiments. Realtime PCRs were performed with DNA Engine (Bio-Rad, Hercules, CA) using QuantiTect SYBR Green RT-PCR Master Mix (Qiagen) with each gene-specific primers (see Table 1 for primers sequences). One microliter of cDNA was amplified in a three-step cycling program in a final reaction volume of $25 \mu \mathrm{l}$. Control cDNA samples (obtained without transcriptase) were always included, as well as samples without any cDNA template. Efficiencies of PCR were calculated for each gene using serial dilution. Reactions were performed in triplicate for five biological replicates, and threshold cycle values were normalized to $\beta$-actin gene expression. The specificity of the products was determined by melting curve analysis, and their correct sizes were analyzed by electrophoresis. The ratio of the relative expression of target genes to $\beta$-actin was calculated by using the $2^{\Delta \mathrm{CT}}$ formula.

Stereotaxic injections. For stereotaxic injections, anesthesia was induced in a closed chamber delivering 5\% halothane combined with $100 \%$ $\mathrm{O}_{2}$ at $2 \mathrm{~L} / \mathrm{min}$. The rats were placed in a Kopf stereotaxic frame and anesthesia maintained by the delivery (via a face mask) of $1.5-2 \%$ halothane combined with $100 \% \mathrm{O}_{2}(1 \mathrm{~L} / \mathrm{min})$. A small incision was made in the scalp to expose the skull and reveal bregma. After craniotomy, animals received an injection of Fluorogold (4\%, $300 \mathrm{nl}$; Fluorochrome, Englewood, NJ) into the parabrachial area ( $\mathrm{mm}$ : anteroposterior, -9.2 , mediolateral \pm 1.7 , dorsoventral, -6.4 , both sides) (Paxinos et al., 1985) delivered by a Hamilton syringe of a total volume of $2.5 \mu$ l. Rats were allowed to recover from anesthesia in an incubation chamber and then transferred back to their home cage for $3 \mathrm{~d}$. On the third day after surgery, 
rats were perfused or received an injection of CFA in the ankle joint, as described above, and were perfused $1 \mathrm{~h}$ later.

Immunohistochemistry. For immunohistochemistry, rats were deeply anesthetized with pentobarbital at $1 \mathrm{~h}$ or $24 \mathrm{~h}$ after CFA injection or naive and perfused transcardially with saline containing $5000 \mathrm{IU} / \mathrm{ml}$ heparin followed by $4 \%$ paraformaldehyde (PFA) in $0.1 \mathrm{~m}$ phosphate buffer (PB; $250 \mathrm{ml}$ per adult rat). Lumbar spinal cord was dissected out, postfixed in the same PFA solution for $2 \mathrm{~h}$, and transferred into a $30 \%$ sucrose solution in $\mathrm{PB}$ containing $0.01 \%$ azide at $4^{\circ} \mathrm{C}$, for a minimum of $24 \mathrm{~h}$. Spinal cords were cut on a freezing microtome set at $40 \mu \mathrm{m}$. Sections were left to incubate with primary antibodies for $48 \mathrm{~h}$ at $4^{\circ} \mathrm{C}$ [prodynorphin (PDYN), 1:50,000, Chemicon, Temecula, CA; FK 506 binding protein 5 (FKBP5), 1:50,000, Santa Cruz Biotechnology, Santa Cruz, CA; serumand glucocorticoid-inducible kinase (SGK1), 1:10,000, MeCP2, 1:20,000, and SIN3A, 1:10,000, Upstate Biotechnology, Lake Placid, NY; phosphorylated MeCP2 (P-MeCP2; S421), 1:10,000, a gift from Zhaolan (Joe) Zhou and Michael Greenberg Children's Hospital, Boston, MA]. Appropriate biotinylated secondary antibodies were used at a concentration of 1:400 and left on for $90 \mathrm{~min}$. Samples were then incubated with avidin biotin complex (ABC Elite; 1:250 Vectastain A plus 1:250 Vectastain B; Vector Laboratories, Burlingame, CA) for 30 min followed by a signal amplification step with biotinylated tyramide solution (1:75 for $7 \mathrm{~min}$; PerkinElmer, Wellesley, MA). Finally, sections were incubated with FITC avidin for another $2 \mathrm{~h}$ (1:600). For the double labeling with Fluorogold antibody, we used an antibody directed at Fluorogold (Fluorochrome). Sections stained for SGK1, FKBP5, SIN3A, MeCP2, or P-MeCP2 were left overnight at room temperature in a solution of Fluorogold antibody $(1: 25,000)$. Direct secondary was used at a concentration of 1:500 (antirabbit Alexa 594). All sections were coverslipped with Gel Mount Aqueous Mounting Medium (Sigma) to protect the fluorescence from fading and stored in dark boxes at $4^{\circ} \mathrm{C}$. In the antisense experiment, to test for antisense and missense oligos toxicity, spinal cord sections were stained with NeuN (a specific neuronal marker) and Hoescht's staining. Controls for immunohistochemistry included omitting the first or second primary antibodies.

Western blots. Fresh tissue was collected as described above (see Tissue collection and RNA preparation) and kept at $-80^{\circ} \mathrm{C}$ until processing. One superficial dorsal horn quadrant of the lumbar area (L4-L6) was homogenized in $250 \mu \mathrm{l}$ of lysis buffer [ $1 \%$ NP-40, 20 mM HEPES, pH 7.4, $100 \mathrm{~mm} \mathrm{NaCl}, 100 \mathrm{~mm} \mathrm{NaF}, 1 \mathrm{~mm} \mathrm{Na}_{3} \mathrm{VO}_{4}, 5 \mathrm{~mm}$ EDTA with $1 \times$ protease inhibitor mixture; $1 \times$ phosphatase inhibitor cocktail I and II (Sigma)] and incubated for $2 \mathrm{~h}$ on ice. Samples were then centrifuged at 13,000 rpm for $15 \mathrm{~min}$, and supernatants were collected. Total protein concentration was assessed using a bicinchoninic acid protein assay kit (Pierce, Rockford, IL). Samples were run on $8 \%$ SDS-PAGE (Bio-Rad) with a loading of $10 \mu \mathrm{g}$ of proteins per well. Proteins were transferred onto a polyvinylidene fluoride membrane (Bio-Rad). Membranes were blocked in $10 \mathrm{~mm}$ Tris- $\mathrm{HCl}$, pH 7.5, $150 \mathrm{~mm} \mathrm{NaCl}, 0.05 \%$ Tween 20 (Sigma), and $0.24 \%$ I-Block (Tropix, Bedford, MA) and incubated with SGK1 antibody $\left(1: 1000\right.$; overnight at $\left.4^{\circ} \mathrm{C}\right)$, FKBP $\left(1: 200\right.$; overnight at $\left.4^{\circ} \mathrm{C}\right)$, or glyceraldehyde-3-phosphate dehydrogenase (GAPDH) (1:2000; $2 \mathrm{~h}$ room temperature; Chemicon, Chandlers Ford, UK). An appropriate HRP-conjugated secondary antibody was incubated for $45 \mathrm{~min}$ (1:2000). HRP activity was visualized by applying a chemiluminescent substrate (ECL; GE Healthcare, Arlington Heights, IL) and using Chemi Doc XRS from Bio-Rad. Signal intensity was measured using Quantity One software (Bio-Rad). The measure of the SGK1 and FKBP5 signal was normalized with the intensity of the GAPDH signal. The mean of this value for control (naive) animals was arbitrarily set to $100 \%$.

Antisense experiment. The 19-base antisense oligodeoxynucleotide was designed according to the sequence of the rat SGK1 (NM_019232) and was targeted around the translation initiation site (nucleotides 108-126 or -3 to +15$)$. The sequence was as follows: $5^{\prime}$-CCATTCCCCTCATTCTG ${ }^{*} \mathrm{G}^{\star} \mathrm{A}-3^{\prime}$. The mismatch probe was a scramble of the antisense: $5^{\prime}$-CAGCCTTTCCTACAGCT ${ }^{\star} \mathrm{C}^{\star} \mathrm{T}-3^{\prime}$. Both oligonucleotides were endcapped with phosphorothioate linkages (at the positions marked by an asterisk) and synthesized by Eurogentec (Seraing, Belgium). None of these probes shows complementing ability to any known sequences according to the GenBank database. Probes were dissolved in
$0.9 \%$ saline at a concentration of $0.25 \mu \mathrm{g} / \mu \mathrm{l}$. For continuous delivery of the oligonucleotides and saline, we used osmotic minipumps (model 2001; Alzet, Cupertino, CA) with a reservoir of $200 \mu \mathrm{l}$ and a fluid delivery rate of $1 \mu \mathrm{l} / \mathrm{h}$. On the day before surgery, minipumps were filled with antisense solution, missense solution, or saline under sterile conditions. A silicone cannula [in mm: 0.635 inner diameter (ID) to 1.2 outer diameter (OD); Biopure, Southampton, UK] of $1 \mathrm{~cm}$ was then attached to the pump, and the pump plus cannula were immersed in $0.9 \%$ saline and kept at $37^{\circ} \mathrm{C}$ overnight. On the day of the surgery, rats $(200 \mathrm{~g})$ were anesthetized in a closed chamber delivering $5 \%$ halothane combined with $95 \% \mathrm{O}_{2}$ at $2 \mathrm{~L} / \mathrm{min}$. Anesthesia was maintained during the surgery by the delivery (via a face mask) of $1.5-2 \%$ halothane combined with $95 \% \mathrm{O}_{2}(1 \mathrm{~L} / \mathrm{min})$. The method chosen for catheter insertion was based on that described by Storkson et al. (1996), which is a quick and relatively noninvasive method. A small incision was made in the skin $10-15 \mathrm{~mm}$ caudal to a line between the ventral iliac spines. A needle, used as guide cannula (20 gauge), was inserted through the incision, directed cranially, and advanced 3-5 $\mathrm{mm}$ into the narrow space between L5 and L6 vertebrae. Before surgery, catheters ( $10 \mathrm{~cm}$ long; in $\mathrm{mm}$ : 0.28 ID to $0.61 \mathrm{OD}$; polythene tubing, Portex Fine Bore) were immersed in hot water and stretched at one end to reduce the diameter by $\sim 60 \%$. A sterile catheter was introduced inside the needle and threaded along the spinal cord for 3 $\mathrm{cm}$, sitting in the intrathecal space. Usually, a tail or paw flick confirmed the correct placement of the catheter. The needle was then carefully removed, avoiding displacement of the catheter. The catheter was fixed to the silicone cannula linked to the minipumps with cyanoacrylic glue. When the glue was dry, the pump was implanted subcutaneously into a pocket formed by separating connective tissues on the flank of the rat. The incision was closed with skin suture clips. After recovery, animals were monitored for signs of body weight loss and motor dysfunction. For successful implantations ( $>70 \%$ of rats), behavioral testing resumed $48 \mathrm{~h}$ after surgery, when animals received an injection of CFA in the ankle joint, as described above. The experimenter did not know which treatment was administered to which animals. Seven days after pump implantation, animals were perfused and checked for catheter placement, and tissue was taken for immunohistochemistry.

Data analysis. For the behavioral experiments, statistical analysis was performed on the raw or normalized data (mean of the control values set arbitrarily at 100\%). The significance of any differences in sensitivity was assessed using repeated-measures two-way or one-way ANOVA (SPSS $\mathrm{PC}^{+}$; SPSS, Chicago, IL), as appropriate. In all cases, a significant effect on the main factor(s), or interactions between them, was taken as the criterion for progressing to ( post hoc) one-way ANOVA. In all cases, 'time' was treated as 'within subjects' factor and 'treatment' was treated as a between subjects factor. Comparisons of changes in different groups of rats were performed on time-matched samples. When appropriate, the Greenhouse-Geisser $\varepsilon$ correction was applied to correct for any violation of sphericity of the variance-covariance matrix.

For RT-qPCR, normalized signals (ratio of the relative expression of target genes to $\beta$-actin calculated by using the $2^{\Delta \mathrm{CT}}$ formula) were compared at different time points by Student's $t$ test or multivariate analysis followed by appropriate post hoc tests (Tukey's), as appropriate ( $n=4 / 5$ in each group).

Upregulation of PDYN and SGK1, $24 \mathrm{~h}$ after injection of CFA, increase in P-MeCP2 $1 \mathrm{~h}$ after CFA, as well as SGK1 downregulation after antisense administration were quantified by immunohistochemistry. For upregulation, immunopositive cells were counted in different areas of the dorsal horn of naive and CFA-injected animals (ipsilateral and contralateral, $24 \mathrm{~h}$ after injection; in each group, $n=3$ for PDYN and $n=4$ for SGK1). Data were analyzed by general linear model multivariate test, followed by appropriate post hoc tests (SPSS PC ${ }^{+}$) or Student's $t$ test, as appropriate. In the SGK1 antisense experiment, immunopositive cells were counted exclusively in lamina I and compared between antisense, missense, and saline-perfused animals. When a multivariate test was applied, there was no difference between the saline- and missense-treated animals, and therefore, both of these treatment groups were pooled and compared with the antisense treatment by Student's $t$ test $(n=4 / 6)$.

For Western blots, normalized SGK1 and FKBP5 signals were compared in naive (control) and treated animals by a Student's $t$ test. Two 
comparisons were made: naive versus $24 \mathrm{~h}$ ipsilateral and naive versus $24 \mathrm{~h}$ contralateral (last comparison only for SGK1; $n=4$ in each group).

For all statistical analysis, statistical significance was set at $p<0.05$.

\section{Results}

\section{Behavioral validation of the model}

Injection of CFA in the rat ankle joint induced very rapid reduction in pain threshold. There was a significant reduction in pain threshold from $2 \mathrm{~h}$ after injection (Fig. $1 A)\left(F_{(1,14)}=6.475 ; p<\right.$ 0.05 , cf. naive; $n=8)$. Maximum sensitivity was reached at $6 \mathrm{~h}$ after injection and maintained for at least $7 \mathrm{~d}$ (Fig. 1A). Automatic Von Frey testing did not reveal any change in threshold in the contralateral side. When sensitivity thresholds were measured in sham animals, we saw no changes over a $7 \mathrm{~d}$ period (data not shown).

\section{Microarray analysis}

Microarrays were run for samples of spinal cord dissected at $0 \mathrm{~h}$ (naive $=$ control), $2 \mathrm{~h}, 6 \mathrm{~h}, 24 \mathrm{~h}$, and $7 \mathrm{~d}$ after CFA injections. When we applied limma testing to calculate the adjusted $p$ values, which correct $p$ values for false positives, we did not find any significant difference, as has also been found by others after microarray analysis of neuropathic rats tissue (Costigan et al., 2002). Therefore, genes were ranked by $p$ value for each of the four comparisons: naive versus $2 \mathrm{~h}, 6 \mathrm{~h}, 24 \mathrm{~h}$, and $7 \mathrm{~d}$. Genes among the top 100 of each list and with an absolute fold-change compared with naive $>1.3$ were selected for additional study. We selected this arbitrary cutoff fold-change in an attempt to reduce false positives. Annotated genes were then classified into functional and biological families such as "regulation of transcription" and "cell-cell signaling" (Fig. 1B) (supplemental Table 1, available at www.jneurosci.org as supplemental material). The proportion of upregulated and downregulated genes differed greatly between the early time points of the experiment and the latest time point (i.e., 7 d) (Fig. $1 B$ ). Specifically, there was predominantly downregulation of gene expression at $7 \mathrm{~d}$ compared with any other time point. Also, only very few genes were significantly differentially expressed when compared with control at more than one time point (Fig. $1 B$, symbols) (e.g., nuclear factor, interleukin 3 regulated was upregulated at $2 \mathrm{~h}, 6 \mathrm{~h}$, and $24 \mathrm{~h}$ after CFA injection when compared with naive).

\section{PDYN mRNA and protein increase in the dorsal horn $24 \mathrm{~h}$ after CFA injection}

After statistical analysis, the three genes with the greatest foldchange increase within 24 h of CFA injection were PDYN, SGK1, and FKBP5. Previous studies have already implicated PDYN in the maintenance of persistent pain states (Millan et al., 1988; Wang et al., 2001). We therefore confirmed by RT-qPCR and immunohistochemistry the increase in PDYN mRNA and protein as a validation of our microarray analysis.

Microarray analysis revealed that $P D Y N$ was highly regulated with a maximum upregulation seen $24 \mathrm{~h}$ after injection (2.0-fold increase) (supplemental Table 1, available at www.jneurosci.org as supplemental material) (Fig. 2A). RT-qPCR confirmed the increase in PDYN mRNA showing a 1.5-fold increase in the ipsilateral side $24 \mathrm{~h}$ after CFA injection ( $p<0.05$, cf. naive) (Fig. $2 A)$. Results obtained by immunohistochemistry also showed a 2.2-fold change increase in the number of PDYN expressing cells on the ipsilateral side in lamina I + II $(p<0.001$, cf. contralateral side) and a 21.5 -fold change increase in lamina III to $\mathrm{V}(p<$ 0.001 , cf. contralateral side) (Fig. $2 B-F$ ). There were no differences in sham animals when comparing the ipsilateral side to the

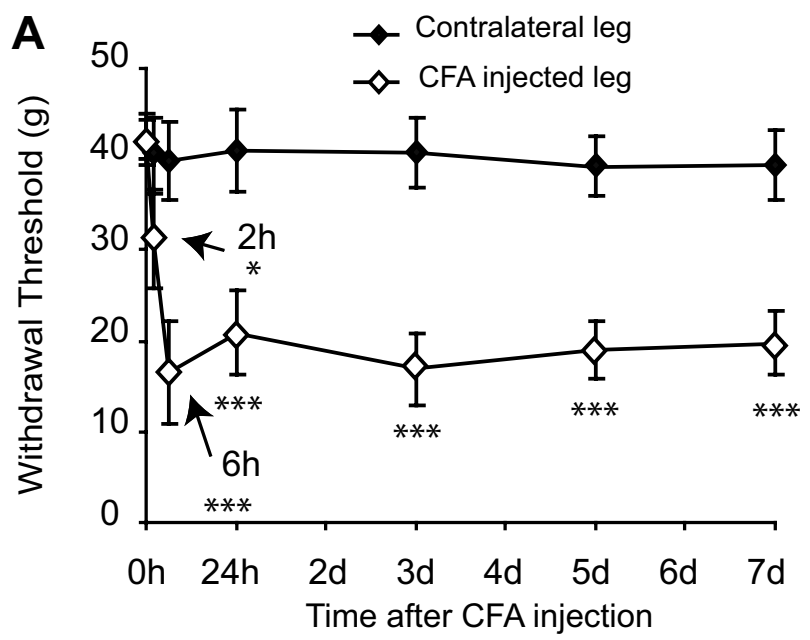

$\left.\begin{array}{ll}\text { B } & 25 \\ & 20\end{array}\right] \quad$ Up-regulation

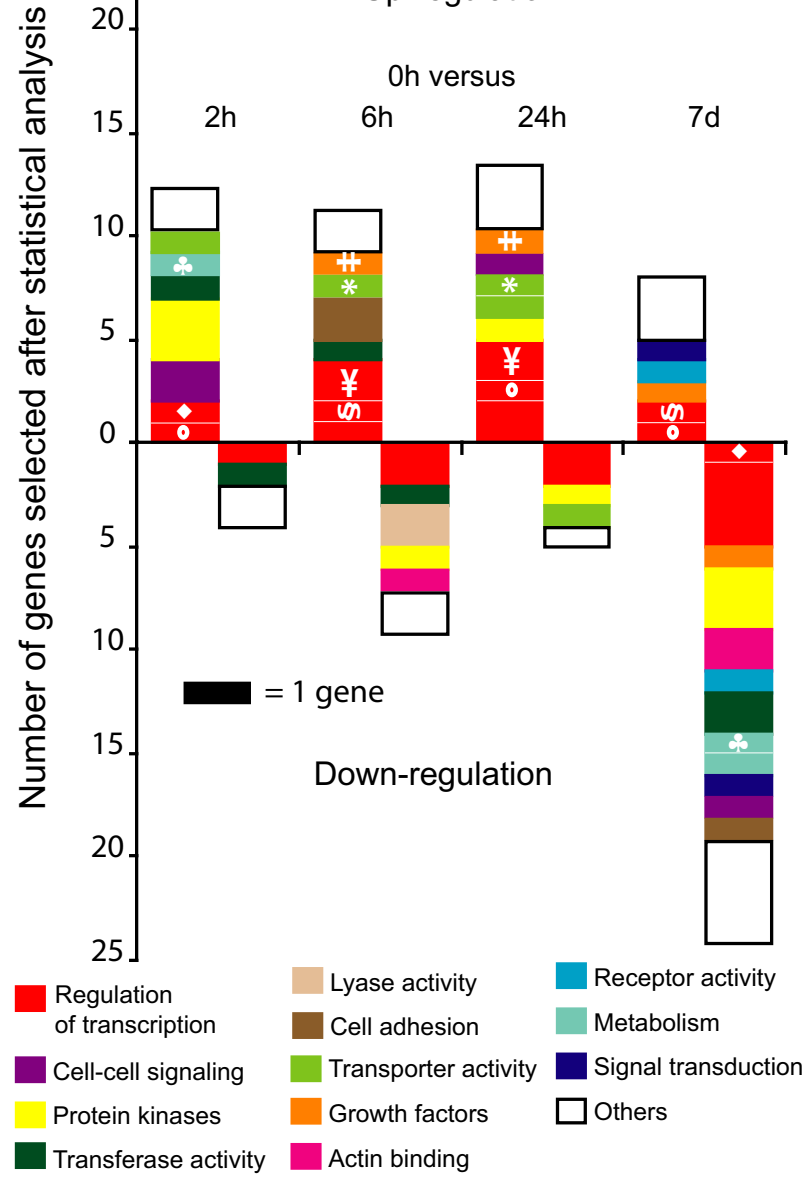

Figure 1. Effects of CFA injection in the ankle joint on pain behavior and genes regulation at $2 \mathrm{~h}, 6 \mathrm{~h}, 24 \mathrm{~h}$, and $7 \mathrm{~d}$ after injection. $\boldsymbol{A}$, Withdrawal threshold to mechanical stimulation (automatic Von Frey) decreased significantly in the ipsilateral side from $2 \mathrm{~h}$ after CFA injection. Maximum sensitivity was reached $6 \mathrm{~h}$ after injection and maintained for at least $7 \mathrm{~d}$. No reduction in pain threshold was detected in the contralateral side $\left({ }^{* * *} p<0.001\right.$, ${ }^{*} p<0.05$, cf. naive; $n=8$ in each group). Data show mean \pm SEM (SEM). $\boldsymbol{B}$, Distribution and functional breakdown of genes regulated after CFA injection. Limma statistical testing (Smyth, 2004) was applied. Four lists of genes were generated by ranking genes by decreasing the $p$ value for each of the four comparisons: naive versus $2 \mathrm{~h}, 6 \mathrm{~h}, 24 \mathrm{~h}$, and $7 \mathrm{~d}$. We selected, for additional study, the genes among the top 100 of each list, which had an absolute fold-change compared with naive $>1.3$ and were annotated. The complete gene list is shown in supplemental Table 1 (available at www.jneurosci.org as supplemental material). Symbols represent the same genes present at more than one time point in the data sets. 

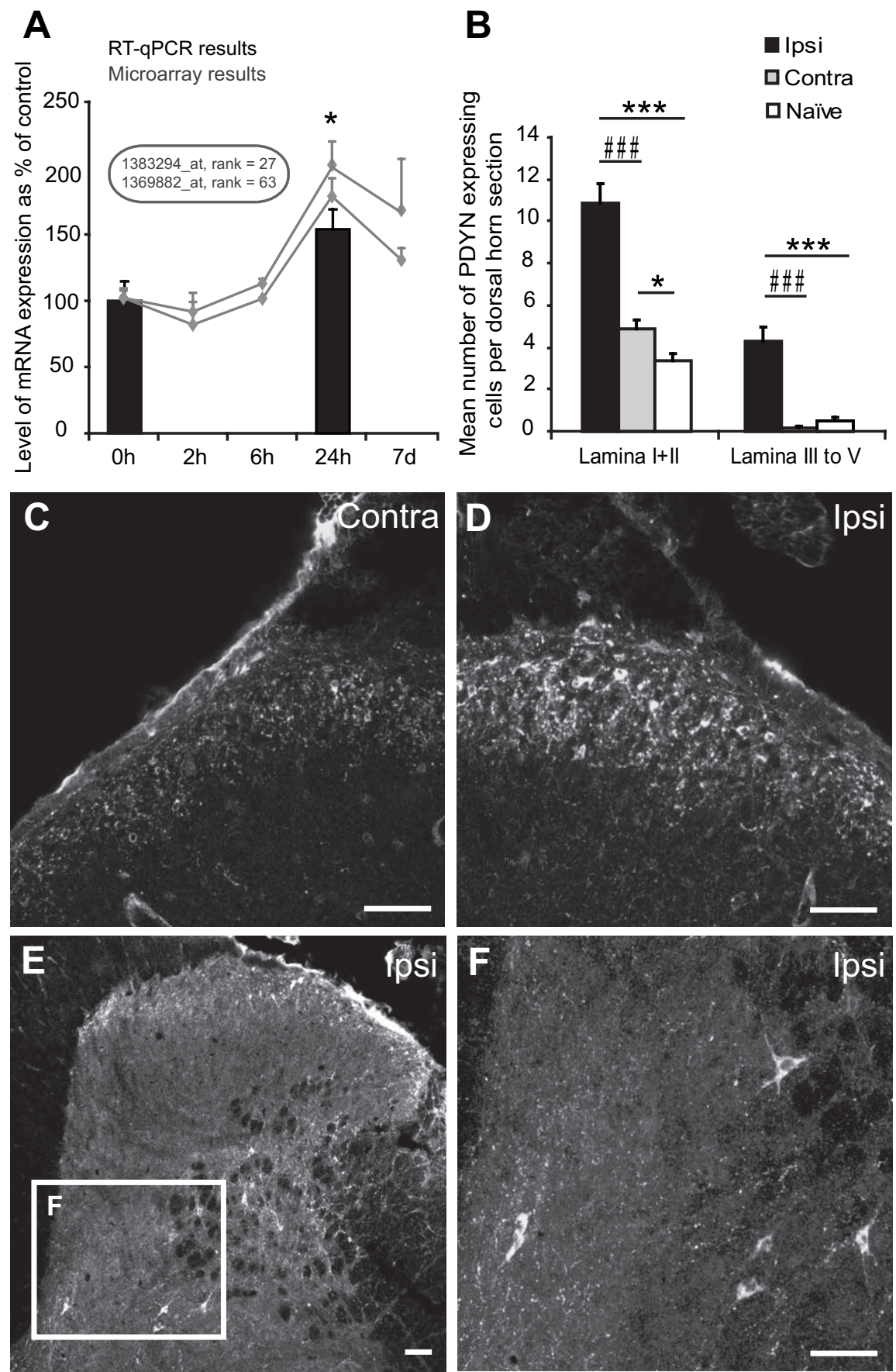

Figure 2. Prodynorphin expression increases in the superficial dorsal horn after CFA injection in the ankle joint. $A$, Microarray analysis revealed a maximum increase for PDYN mRNA expression $24 \mathrm{~h}$ after $C F A$. This increase was confirmed by RT-qPCR: there was a 1.5 -fold increase in the ipsilateral side $24 \mathrm{~h}$ after CFA injection $\left(n=5\right.$ in each group; $\left.{ }^{*} p<0.05\right)$. Data show mean \pm SEM $B$, Effects of CFA injection on PDYN immunoreactivity. Counts of immunoreactive cells showed a significant increase in PDYN protein in the ipsilateral side (ipsi) compared with naive and contralateral side (contra), both in lamina I+ II and lamina III to V, $24 \mathrm{~h}$ after CFA. There was also an increase in the contralateral side in lamina I+ II when compared with naive. Results were obtained from three animals and $10-15$ spinal cord sections for each animal; ipsi versus naive or contra versus naive: ${ }^{* * *} p<$ $0.001,{ }^{*} p<0.05$; ipsi versus contra ${ }^{\# \#} p<0.001$. C $\boldsymbol{F}$ show typical confocal images of PDYN immunoreactivity in dorsal horn on the contralateral side $(\boldsymbol{C})$ and ipsilateral side $(\boldsymbol{D}-\boldsymbol{F}) 24 \mathrm{~h}$ after CFA injection. Data show mean \pm SEM. Scale bars, $40 \mu \mathrm{m}$.

contralateral side and naive (data not shown). Ten to 15 sections were analyzed for three animals for each treatment.

Genes associated with $\mathrm{MeCP} 2$ repression are regulated in the dorsal horn after joint inflammation

The most striking finding after microarray analysis was the presence, 2-24 h after inflammation, of a small number of highly regulated transcripts, the expression of which has been shown previously to be regulated after the genetic deletion of the transcriptional repressor MeCP2 (Nuber et al., 2005). These included SGK1, which has been linked previous to LTP in the hippocampus and learning and memory, FKBP5 and the sulfotransferase family $1 A$, phenol-preferring, member 1 (SULT1A1) (fold-changes of 3.2, 3.0, and 1.5, respectively) (supplemental Table 1, available at www.jneurosci.org as supplemental material). Moreover, microarray results also suggested that the expression of the transcriptional regulator $\operatorname{SIN} 3 A$, a corepressor in the MeCP2 complex, was downregulated after CFA injection (1.5-fold change) (supplemental Table 1, available at www. jneurosci.org as supplemental material). The Ubiquitin protein ligase E3A (UbE3A), which has been linked to $\mathrm{MeCP} 2$, was also one of the short listed genes following statistical analysis (supplement Table 1, available at www.jneurosci.org as supplemental material).

We used RT-qPCR to validate the increase in message of all of the genes selected after statistical analysis that were linked to $\mathrm{MeCP} 2$ translational repression (Fig. 3A). For this, we used the results obtained after microarray analysis (supplemental Table 1, available at www. jneurosci.org as supplemental material) as a guide to the appropriate time points to be explored. However, given the limited sensitivity of microarrays (Costigan et al., 2002), RT-qPCR validations were generally made at more than one time point to determine maximum change of gene expression.

Compared with naive animals, we found a twofold increase of SGK1 expression $6 \mathrm{~h}$ after CFA (effect of time in the multivariate analysis: $F_{(3,15)}=3.68 ; p<$ 0.05 ), a 1.3 -fold increase of $F K B P 5$ expression $2 \mathrm{~h}$ after CFA (Student's $t$ test; $p<$ 0.01 ), a 1.5-fold increase of SULT1A1 expression $6 \mathrm{~h}$ after $\operatorname{CFA}\left(F_{(2,9)}=5.23\right.$; $p<$ $0.05)$, a 2.2 -fold decrease of SIN $3 A$ expression $6 \mathrm{~h}$ after CFA $\left(F_{(2,12)}=7.95 ; p<\right.$ 0.01 ), and a 1.4 -fold decrease of $U b E 3 A$ expression $6 \mathrm{~h}$ after $\operatorname{CFA}\left(F_{(2,12)}=4.45\right.$; $p<0.05)$.

Three of these genes have been shown to be glucocorticoids-regulated (SGK1, FKBP5, and SULT1A1). Therefore, to confirm that the changes in expression observed in this study were not induced by stress, we compared gene expression between CFA-treated animals and sham animals at the time point of maximum regulation for each of the validated genes. When comparing to sham animals at $2 \mathrm{~h}$, we found a 1.3 -fold increase of FKBP5 expression $(p<0.05)$. At $6 \mathrm{~h}$, there was a 4.4 -fold increase of SGK1 expression $(p<0.01)$, a 2.5 -fold 
increase of SULT1A1 expression $(p<$ $0.05)$, a 2.3 fold decrease of SIN $3 A$ expression $(p<0.001)$, and a 1.3-fold decrease of $U b E 3 A$ expression $(p<0.05)$.

From this analysis, we designed experiments to investigate the distribution of SGK1, MeCP2, and other genes known to be repressed by $\mathrm{MeCP} 2$, in specific populations of dorsal horn neurons. We also assessed the contribution of SGK1 to the induction and maintenance of inflammatory pain behaviors.

\section{Genes associated with MeCP2 repression are present in a subpopulation of lamina I projections neurons}

Staining of spinal cord sections of naive animals for SGK1, FKBP5, and SIN3A confirmed the presence of these proteins in a high proportion of neurons within the superficial dorsal horn. Double staining for MeCP2 and NeuN showed that MeCP2 was expressed by all dorsal horn neurons. To explore whether these proteins were expressed in lamina I projection neurons, animals received an injection of retrograde tracer Fluorogold into the parabrachial area and were killed and perfused $3 \mathrm{~d}$ after the injection. We found that SGK1, FKBP5, SIN3A, and, as expected, $\mathrm{MeCP} 2$ were all expressed in lamina I projections neurons (Fig. 3B-E). In particular, we counted the number of cells in the superficial dorsal horn labeled for SGK1 and Fluorogold. In lamina I, $6.4 \pm 0.4$ neurons were labeled with Fluorogold antibody per half spinal cord section, and $56 \pm 3 \%$ of these expressed SGK1 (5-10 sections were analyzed for three animals).

\section{Increase in SGK1 and FKBP5 protein in} dorsal horn after joint inflammation Using Western blot analysis, we found a 2.7-fold increase in FKBP5 protein expression in the ipsilateral side when compared with naive $(p<0.01 ; n=4$ in each group) (Fig. 4) $6 \mathrm{~h}$ after CFA injection. Protein levels returned to basal levels by $12 \mathrm{~h}$ (results not shown). Western blot analysis also revealed a 1.3-fold increase of SGK1 protein expression in the ipsilateral side at $24 \mathrm{~h}$ when compared with naive $(p<$ $0.05 ; n=4$ in each group) (Fig. 4). There was no significant increase in the contralateral side at $24 \mathrm{~h}$ (data not shown).

We further characterized the increase in SGK1 protein by immunohistochemistry (Fig. 5). SGK1 is abundantly expressed in the dorsal horn. We noted the expression of SGK1 in the medial area of the superficial dorsal horn lamina I (Fig. 5A-C), and in neurons with radially orientated processes in lamina III (Fig. $5 D, E)$. Twenty-four hours after CFA injection, we found a sig-
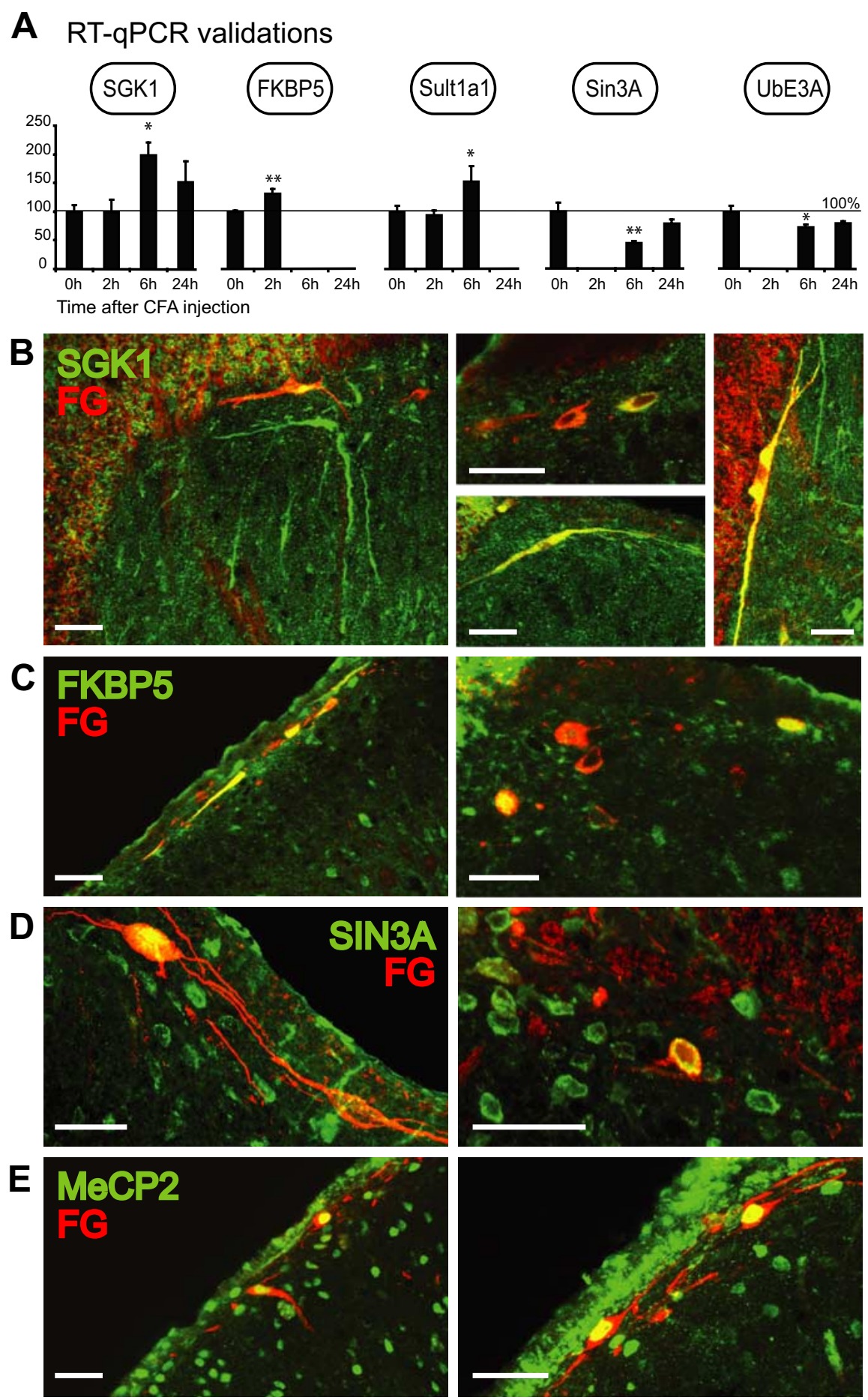

Figure 3. Expression of genes associated with MeCP2 transcriptional repression. $\boldsymbol{A}$, We confirmed by RT-qPCR the significant regulation of SGK1, FKBP5, SULT1A1, SIN3A, and UbE3A mRNA after CFA injection, as suggested by microarray analysis. The $y$-axis represents mRNA expression as percentage of control. Data show mean \pm SEM. B, SGK1, FKBP5, SIN3A, and MeCP2 are expressed in lamina I projection neurons. Fluorogold, a retrograde tracer, was injected into the parabrachial area of naive animals to label lamina I projection neurons. $\boldsymbol{B}-\boldsymbol{D}$, Spinal cord sections were double labeled with antibodies against SGK1 (B), FKBP5 (C), SIN3A $(\boldsymbol{D})$, and MeCP2 (E) (green) and an antibody against Fluorogold (red). Double-labeling resulted in yellow staining. Images were made using confocal microscopy. SGK1, FKBP5, SIN3A, and MeCP2 were all expressed in subpopulations of lamina I projections neurons. FG, Fluorogold. Scale bars, $40 \mu \mathrm{m}$.

nificant 1.3 -fold increase $(p<0.05)$ in the number of lamina I to V neurons immunopositive for SGK1 on the ipsilateral side when compared with the contralateral side. Importantly, the number of mediolaterally orientated dendrite-like profiles in lamina I (Fig. 


\section{Western Blots}
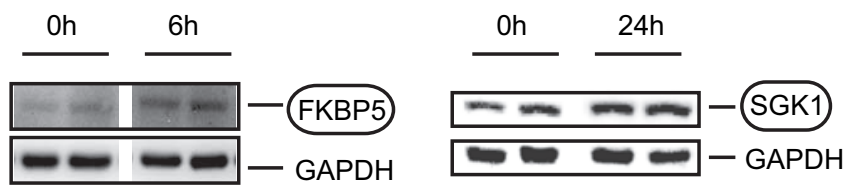

Figure 4. FKBP5 and SGK1 protein expression increases after CFA injection. Immunoblots were probed with FKBP5 or SGK1 antibodies after gel electrophoresis of lysates from spinal cord segments L4 - L6 from naive or CFA-injected animals.
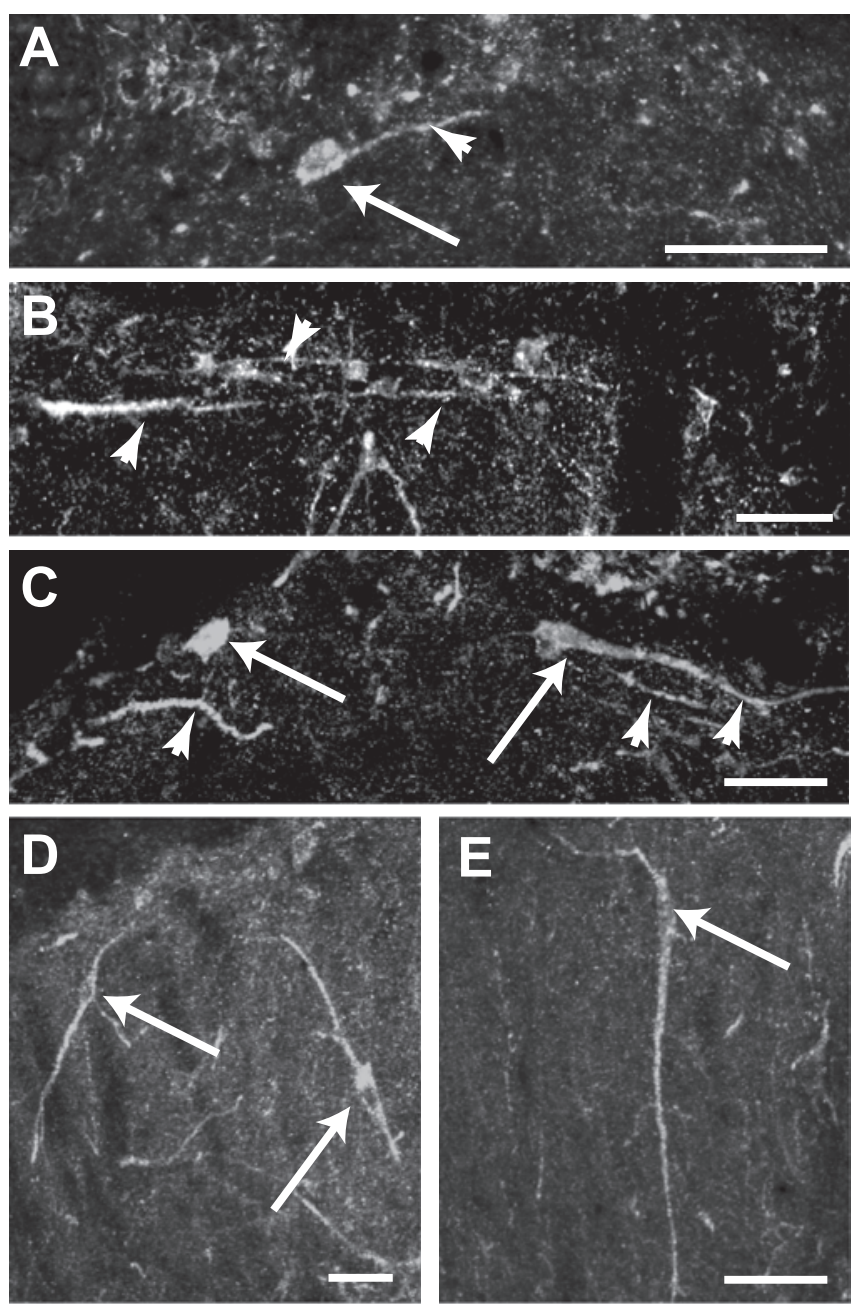

Figure 5. Expression of SGK1 protein in the superficial dorsal horn. A-C, SGK1 immunoreactivity in lamina I and II. SGK1 was expressed in lamina I cells (as shown by arrows) but also in mediolaterally orientated dendrite-like profiles often associated with labeled cell bodies ( $\boldsymbol{B}$; arrowheads). D, E, SGK1 immunoreactivity in neurons with radial processes in the medial dorsal horn in lamina III. Arrows indicate cell bodies, and arrowheads indicate dendrite-like profiles. Pictures were taken using confocal microscopy. Data show mean \pm SEM. Scale bars, $40 \mu \mathrm{m}$.

$5 B)$ were greater on the ipsilateral side than on the contralateral side ( $4.6 \pm 0.4$ and $2 \pm 0.3$, respectively; $p<0.001$ ).

\section{Phosphorylation of MeCP2 increases after noxious stimulation}

To show that relief of $\mathrm{MeCP} 2$ repression was potentially occurring in the dorsal horn, we examined the influence of noxious stimulation on the phosphorylation state of MeCP2. Phosphorylation of $\mathrm{MeCP} 2$ has been shown to result in the dissociation of the protein from target gene DNA (Chen et al., 2003; Martinowich et al., 2003) (Fig. 6A). One hour after CFA injection in the ankle joint, we were able to detect an increase in P-MeCP2 immunoreactivity in subsets of neurons scattered throughout the ipsilateral dorsal horn (Figs. 6B1-2, 7), particularly in lamina I and II. The number of $\mathrm{P}-\mathrm{MeCP} 2$ neurons was greater on the ipsilateral side than on the contralateral side in lamina III to V $\left(17 \pm 3.5\right.$ neurons per $0.03 \mathrm{~mm}^{2}$ vs $\left.9.5 \pm 2.4 ; p<0.01\right)$ and lamina I/II $\left(11.1 \pm 1\right.$ neurons per $0.004 \mathrm{~mm}^{2}$ vs $2.7 \pm 0.6$, respectively; $p<0.01$ ). Immunoreactivity was counted in 5-10 sections per animals for three animals. We also found an increase in the number of identified lamina I/II projection neurons immunopositive for P-MeCP2 $1 \mathrm{~h}$ after peripheral stimulation. On the ipsilateral side, 1 out of 3.7 Fluorogold-labeled neurons was positive for $\mathrm{P}-\mathrm{MeCP} 2$, whereas only 1 out of 17.2 cells was labeled on the contralateral side (significantly different; $p<0.001$ ) (Fig. 6B3-6).

\section{Local antisense knock-down of SGK1 delays the onset of pain behavior}

SGK1 has been implicated previously in learning and memory and synaptic plasticity in the hippocampus (Tsai et al., 2002; Ma et al., 2006), suggesting that it may play an important role in neuronal plasticity in the dorsal horn. Therefore, the effect of SGK1 local knock-down on pain threshold was investigated using intrathecal antisense perfusion. Animals were continuously perfused with SGK1 antisense RNA, missense RNA, or saline, and withdrawal thresholds were measured using the Randall-Selitto test at various time points $(6,24,48$, and $96 \mathrm{~h})$ after CFA injection in the ankle joint. There was a significant effect of time and treatment over the time period $0-24 \mathrm{~h}\left(F_{(2,28)}=19.164, p<0.001\right.$, and $F_{(2,14)}=7.986, p<0.01$, respectively). Precisely, we found a significant delay in the onset of increased mechanical sensitivity in animals receiving antisense when compared with both saline and missense $(p<0.05$ and $p<0.01$, respectively; Bonferonni post hoc test for treatment factor) (Fig. 7A). There was no difference between the saline- and the missense-treated animals. By $48 \mathrm{~h}$, the three groups of animals showed the same pain threshold ( $n=5-7$ animals per group).

To quantify the efficiency of the protein knock-down, we counted the number of lamina I cells immunopositive for SGK1 in the three groups of animals. Again, there was no difference between the missense- and saline-treated animals, and we pooled the animals for these two treatments into one group. When compared with the antisense-treated animals, there was a significant decrease of $61 \%$ in lamina I neurons expressing SGK1 $(p<$ 0.001 ) but not deeper lamina III to V. Hoescht and NeuN staining indicated that both antisense and missense oligos, at the concentration used in this study, did not cause cell damage (data not shown).

\section{Discussion}

Inflammation of peripheral tissues causes spontaneous pain and increased mechanical and thermal sensitivity that is generated by peripheral sensitization of nociceptive primary afferents and amplified by dorsal horn neurons, particularly lamina I projection neurons (Nichols et al., 1999; Ikeda et al., 2006). Using microarray screening of gene expression in dorsal horn neurons as our start point, we characterized the temporal sequence of gene expression that accompanies the development of inflammatory joint pain, identified a putative role for modulation of gene repression by the MeCP2 complex in controlling subsets of specific 
genes, and more specifically identified a role for SGK1 in the induction of inflammatory pain states.

Temporal changes in gene expression Many of the changes in gene expression and second messenger pathways and posttranslational modifications of neurotransmitter receptors previously identified in the hippocampus after LTP or learning and memory have also been seen in the dorsal horn after noxious stimulation (Ji et al., 2003). Previous studies of long-term contextual memory in the hippocampus have identified temporal patterns of gene expression that involve an initial burst of gene regulation $1 \mathrm{~h}$ postcontextual training followed by a period of gene repression and a second wave of gene expression 4-6 h later (Levenson et al., 2004; von Hertzen and Giese, 2005). Our study has also shown that waves of gene expression follow the initial inflammatory stimulus (CFA injection in the ankle joint) with distinct patterns of gene expression at each of the time points studied but with predominantly gene repression at the latest time point $(7 \mathrm{~d})$. These data would suggest that the induction and maintenance of pain states are under the control of different programs of gene expression. This hypothesis is supported by previous findings. For example, in the hippocampus, the rapid induction of the immediateearly gene zif268 was critical for longterm, but not short-term, retrieval of memory and is paralleled by a reduction in long-term LTP but not short-term LTP (Jones et al., 2001). Similarly, zif268 is rapidly induced in dorsal horn neurons within $30 \mathrm{~min}$ of noxious stimulation (Wisden et al., 1990) and has been shown to be important for the maintenance of inflammatory pain states but not for their induction (Rygh et al., 2006). An increase in zif268 mRNA expression was not picked up in the current screen, probably because the first time point sampled was $2 \mathrm{~h}$. However, we confirmed the unilateral increase in spinal PDYN seen in monoarthritic rats (Weihe et al., 1989) and in rats inflamed in the hindpaw (Millan et al., 1988; Zhang et al., 2004a,b) in our more restricted model of joint inflammation. Again, previous findings, together with those presented here, suggest that prodynorphin is critical for the maintenance of inflammatory (Millan et al., 1988) and neuropathic pain states (Wang et al., 2001) but not their induction.

\section{SGK1 and plasticity}

Although genes such as zif268 and PDYN may be closely related to the maintenance phase of the pain state, SGK1 (identified from the present study) appeared to be related to the induction of the inflammatory pain state. SGK1 is a serine and threonine protein

B

\section{A Repression of transcription by the MeCP2 complex}
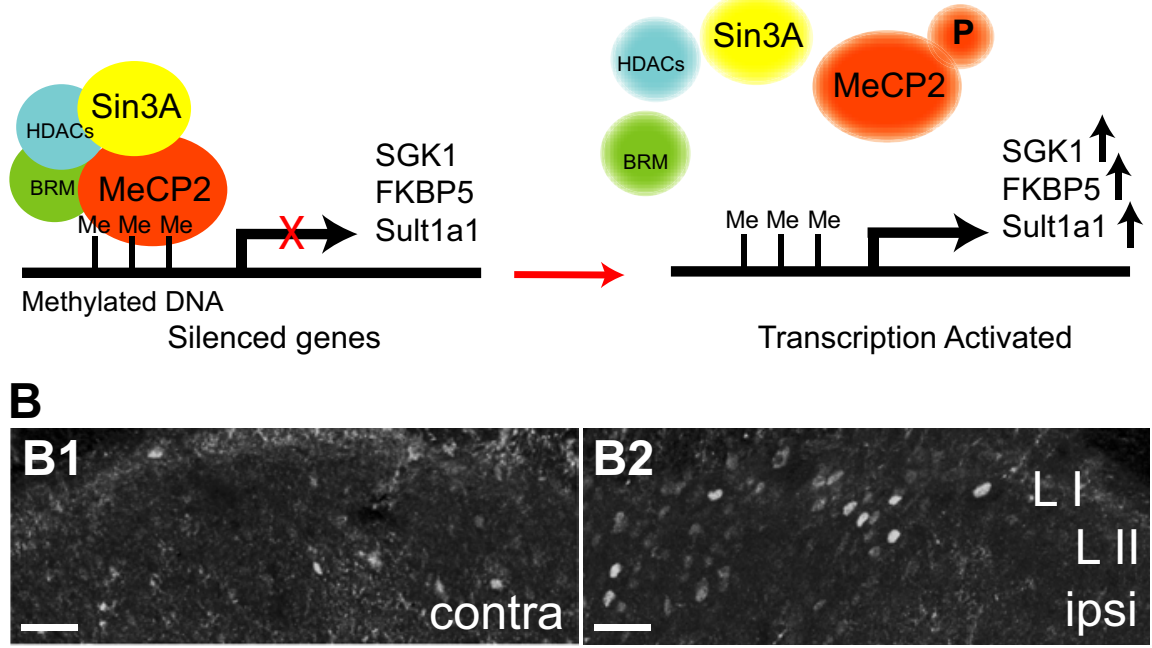

\section{B7}
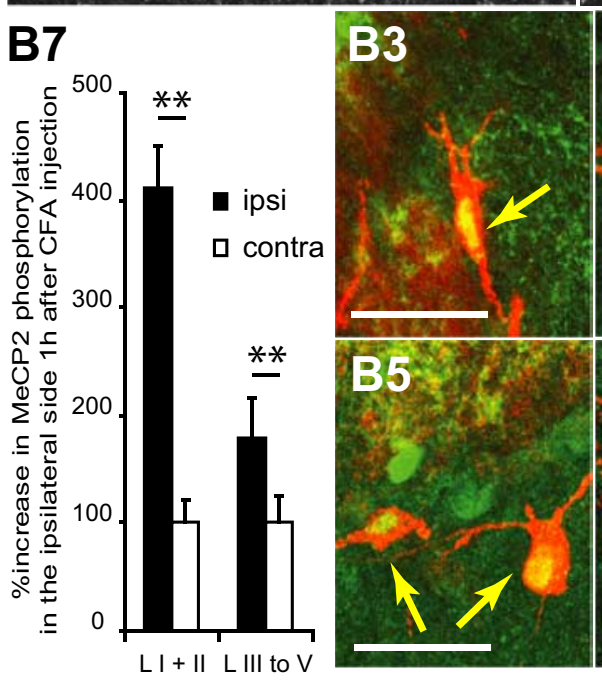

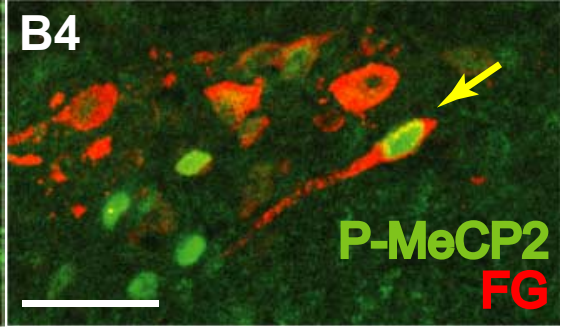

Figure 6. Repression of transcription by the MeCP2 complex and increase in MeCP2 phosphorylation. $\boldsymbol{A}$, Repression of transcription by the MeCP2 complex. MeCP2 binds to promoter regions with methylated CpGs and recruits chromatin-remodeling complexes that contain SIN3A, Brahma (BRM; a SWI/SNF-related chromatin remodeling protein), and histone deacetylases (HDACs). As a consequence, the transcriptional machinery has limited access to the promoter region, and transcription is silenced (Bienvenu and Chelly, 2006). When MeCP2 is phosphorylated, the repression complex is released from the methylated DNA, and transcription factors can then bind to the promoter region. Transcription is activated. $\boldsymbol{B} 1-\mathbf{B 2}, \mathrm{P}-\mathrm{MeCP} 2$ immunoreactivity in the superficial dorsal horn $1 \mathrm{~h}$ after CFA injection in the ankle joint. B3-B6, Spinal cord sections were double labeled with an antibody against P-MeCP2 (green) and an antibody against Fluorogold (red). Double-labeling resulted in yellow staining. Pictures were taken using confocal microscopy. P-MeCP2 was expressed in subpopulations of lamina I projection neurons. FG, Fluorogold. Yellow indicate double-labeled cells. Scale bars, $40 \mu \mathrm{m}$. B7, There was a significant increase in P-MeCP2 in the ipsilateral side when compared with the contralateral side, in lamina I/II and lamina III to V. Results were obtained from three animals and 5-10 spinal cord sections from each animal $\left({ }^{* *} p<0.01\right)$. Data show mean \pm SEM.

kinase activated by the mitogen-activated protein/extracellular signal-regulated kinase signaling pathway (Lee et al., 2006) and known to activate many downstream molecules, including cAMP response element-binding protein (David and Kalb, 2005). SGK1 has been implicated previously in learning and memory and synaptic plasticity (Tsai et al., 2002; Ma et al., 2006). SGK1 is expressed during the consolidation phase of long-term memory (von Hertzen and Giese, 2005) and was shown to facilitate the expression of long-term potentiation in hippocampal neurons (Ma et al., 2006). Together, these results suggest that SGK1 may play an important role in neuronal plasticity in the dorsal horn and support our choice of SGK1 as a candidate gene for modulating synaptic plasticity in pain states. In the present study, we 

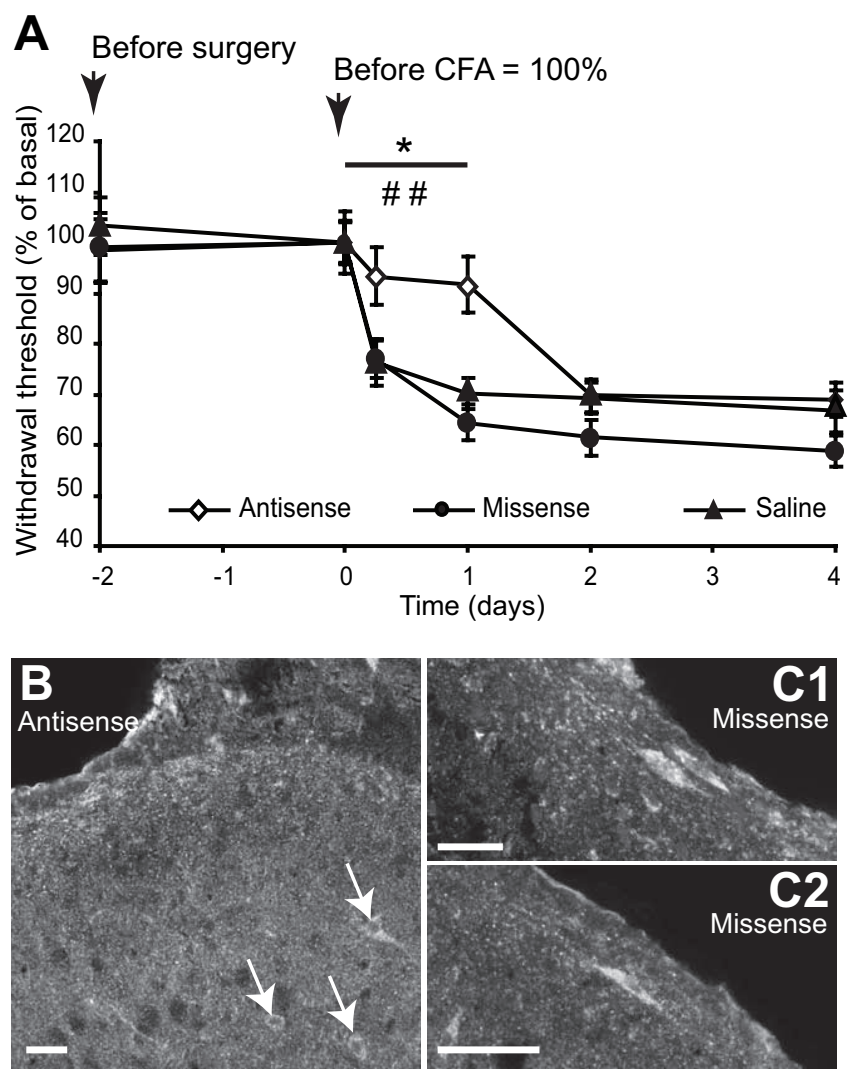

Figure 7. SGK1 antisense oligonucleotide delays change in pain sensitivity and reduces SGK1 immunoreactivity. $A$, Attenuation of behavioral nociceptive responses measured by the withdrawal threshold to the Randall-Selitto test was observed for $24 \mathrm{~h}$ after CFA administration after continuous infusion of the SGK1 antisense oligonucleotide, compared with saline-infused controls $\left({ }^{*} p<0.05\right)$ and missense infused controls ( $\left.{ }^{\# \#} p<0.01\right)$. By $48 \mathrm{~h}$, the three groups of animals showed the same level of sensitivity ( $n=5-7$ in each group). Data show mean \pm SEM. $B, C$, Typical immunoreactivity for SGK1 in superficial dorsal horn after continuous infusion of SGK1 antisense $(\boldsymbol{B})$ and missense $(\boldsymbol{C})$ oligonucleotide. Arrows indicate deep neurons (lamina III to $V$ ) expressing SGK1 after antisense treatment.

found that SGK1 is expressed in lamina I projection neurons and that SGK1 protein levels increase in dorsal horn neurons within lamina I after inflammation. The infusion of antisense probes reduced SGK1 expression in lamina I neurons and delayed the onset of pain for at least $24 \mathrm{~h}$. However, induction of the pain state was not prevented and appeared by $48 \mathrm{~h}$ after inflammation. This may well be because $S G K 1$ is one of several genes involved in the setting-up of pain states.

SGK1 may influence synaptic efficacy through upregulation of postsynaptic density-95 (PSD-95), a scaffolding protein that is enriched in the postsynaptic structure and is upregulated after synaptic activation (Okabe et al., 1999). It has been shown that constitutively active SGK1, activated at Ser422, can increase PSD-95 protein level in the hippocampus (Ma et al., 2006), possibly via translational regulation. Interestingly, antisense knockdown of PSD-95, which we also found expressed in lamina I projections neurons (data not shown), also delayed the development of neuropathic pain in rats (Tao et al., 2001). In spinal cord neurons, PSD-95 was shown to interact with the NMDA receptor subunits $2 \mathrm{~A} / 2 \mathrm{~B}$, increasing its availability at the synapse, and such an interaction was required for noxious thermal hyperalgesia triggered via the NMDA receptor at the spinal cord level (Tao et al., 2000). One could expect that this interaction could also play a role in the induction of a chronic inflammation pain state such as the one studied here.
Another gene singled out in our study, which was also implicated in synaptic plasticity and expressed in lamina 1 projection neurons is FKBP5, a glucocorticoid receptor-regulating cochaperone of hsp-90. In the present study, FKBP5 protein expression increased in the dorsal horn $6 \mathrm{~h}$ after inflammation. Recent research has shown that FKBP5 directly regulates glucocorticoid receptor activity (Wochnik et al., 2005; Westberry et al., 2006) and is implicated in the development of opiate dependence (McClung et al., 2005).

\section{$\mathrm{MeCP} 2$ and gene repression}

A significant proportion of highly regulated genes in our study, including SGK1, FKBP5, and SULT1A1, have been identified from a microarray analysis of brain from mice with a disruption of the $M e C P 2$ gene, a mutation previously identified as causal in Rett disease and characterized by a progressive developmental restriction of synaptic plasticity (Bienvenu and Chelly, 2006). $\mathrm{MeCP} 2$ is a methyl-CpG binding protein that represses gene transcription of specific genes by binding to methylated DNA at methyl-CpG sites and recruiting inactive chromatin remodeling complexes (Fuks et al., 2003; Nan et al., 1998a,b). Membrane depolarization can result in the calcium-dependent phosphorylation and release of MeCP2 from the promoter region thereby facilitating transcription (Chen et al., 2003). In this study, we found that $\mathrm{MeCP} 2$ is phosphorylated after peripheral noxious stimulation in dorsal horn neurons, including lamina I projection neurons. We also found that SGK1, FKBP5, and SULT1A1 were present in lamina I projection neurons and were upregulated in the dorsal horn within $24 \mathrm{~h}$ of the CFA injection. Binding of MeCP2 in promoter-proximal regions of SGK1 and FKBP5 was demonstrated in the brain using chromatin immunoprecipitation and was shown to repress $S G K 1$ and FKBP5 expression in the mouse (Guy et al., 2001; Nuber et al., 2005). Because the presence of MeCP2 in a cell does not prevent the expression of either gene, it was suggested that its role was not to silence these genes but to modulate their level of expression, as has been shown to be the case with BDNF (Chen et al., 2003; Martinowich et al., 2003).

MeCP2 inhibits transcription by recruitment of a corepressor complex containing SIN3A (Martinowich et al., 2003; Suzuki et al., 2003; Klose and Bird, 2004), and we show here a downregulation of SIN3A mRNA (but not MeCP2 mRNA) during the onset of the inflammatory pain model. Although there is no reported downregulation of SIN3A expression in mouse models of Rett syndrome or Rett syndrome patients, a decrease in SIN3A expression, as seen here, would accentuate a decrease in MeCP2 mediated transcriptional repression. SIN3A is also displaced from the BDNF gene promoter by depolarization (Martinowich et al., 2003 ) leading to increased gene expression. Another MeCP2 target gene present in our data set was $U b E 3 A$. Expression of $U b E 3 A$, a gene implicated in autism and Angelman syndrome, is regulated by MeCP2 (Samaco et al., 2005), and this may explain its increased expression in our data set.

\section{Conclusions}

In summary, we provide evidence that, after peripheral inflammation, the gene repressor MeCP2 is phosphorylated in subsets of dorsal horn neurons, specifically lamina I projection neurons, leading to increased expression of a group of genes, including SGK1, FKBP5, and SULT1A1. These three genes have also been shown to be glucocorticoid regulated, suggesting another common level of regulation (Nuber et al., 2005). Previous research has shown that MeCP2 is important for short-term synaptic plas- 
ticity and LTP at Schaffer collateral synapses (Moretti et al., 2006). The evidence presented here strongly suggests that phosphorylation of MeCP2 in dorsal horn neurons by noxious peripheral stimulation may also be important in programming the molecular changes essential for the support of the early phases of central sensitization.

\section{References}

Bailey CH, Bartsch D, Kandel ER (1996) Toward a molecular definition of long-term memory storage. Proc Natl Acad Sci USA 93:13445-13452.

Bennett MI, Attal N, Backonja MM, Baron R, Bouhassira D, Freynhagen R, Scholz J, Tolle TR, Wittchen HU, Jensen TS (2007) Using screening tools to identify neuropathic pain. Pain 127:199-203.

Bienvenu T, Chelly J (2006) Molecular genetics of Rett syndrome: when DNA methylation goes unrecognized. Nat Rev Genet 7:415-426.

Chen WG, Chang Q, Lin Y, Meissner A, West AE, Griffith EC, Jaenisch R, Greenberg ME (2003) Derepression of BDNF transcription involves calcium-dependent phosphorylation of MeCP2. Science 302:885-889.

Costigan M, Befort K, Karchewski L, Griffin RS, D'Urso D, Allchorne A, Sitarski J, Mannion JW, Pratt RE, Woolf CJ (2002) Replicate highdensity rat genome oligonucleotide microarrays reveal hundreds of regulated genes in the dorsal root ganglion after peripheral nerve injury. BMC Neurosci 3:16.

Dahlquist KD, Salomonis N, Vranizan K, Lawlor SC, Conklin BR (2002) GenMAPP, a new tool for viewing and analyzing microarray data on biological pathways. Nat Genet 31:19-20.

David S, Kalb RG (2005) Serum/glucocorticoid-inducible kinase can phosphorylate the cyclic AMP response element binding protein, CREB. FEBS Lett 579:1534-1538.

Doniger SW, Salomonis N, Dahlquist KD, Vranizan K, Lawlor SC, Conklin BR (2003) MAPPFinder: using Gene Ontology and GenMAPP to create a global gene-expression profile from microarray data. Genome Biol 4:R7.

Doyle CA, Hunt SP (1999) Substance P receptor (neurokinin-1)-expressing neurons in lamina I of the spinal cord encode for the intensity of noxious stimulation: a c-Fos study in rat. Neuroscience 89:17-28.

Fuks F, Hurd PJ, Wolf D, Nan X, Bird AP, Kouzarides T (2003) The methylCpG-binding protein MeCP2 links DNA methylation to histone methylation. J Biol Chem 278:4035-4040.

Garry EM, Fleetwood-Walker SM (2004) Organizing pains. Trends Neurosci 27:292-294.

Gentleman RC, Carey VJ, Bates DM, Bolstad B, Dettling M, Dudoit S, Ellis B, Gautier L, Ge Y, Gentry J, Hornik K, Hothorn T, Huber W, Iacus S, Irizarry R, Leisch F, Li C, Maechler M, Rossini AJ, Sawitzki G, et al. (2004) Bioconductor: open software development for computational biology and bioinformatics. Genome Biol 5:R80.

Guy J, Hendrich B, Holmes M, Martin JE, Bird A (2001) A mouse Mecp2null mutation causes neurological symptoms that mimic Rett syndrome. Nat Genet 27:322-326.

Hunt SP, Mantyh PW (2001) The molecular dynamics of pain control. Nat Rev Neurosci 2:83-91.

Ikeda H, Heinke B, Ruscheweyh R, Sandkuhler J (2003) Synaptic plasticity in spinal lamina I projection neurons that mediate hyperalgesia. Science 299:1237-1240.

Ikeda H, Stark J, Fischer H, Wagner M, Drdla R, Jager T, Sandkuhler J (2006) Synaptic amplifier of inflammatory pain in the spinal dorsal horn. Science 312:1659-1662.

Ji RR, Kohno T, Moore KA, Woolf CJ (2003) Central sensitization and LTP: do pain and memory share similar mechanisms? Trends Neurosci 26:696-705.

Jones MW, Errington ML, French PJ, Fine A, Bliss TV, Garel S, Charnay P, Bozon B, Laroche S, Davis S (2001) A requirement for the immediate early gene Zif268 in the expression of late LTP and long-term memories. Nat Neurosci 4:289-296.

Khasabov SG, Rogers SD, Ghilardi JR, Peters CM, Mantyh PW, Simone DA (2002) Spinal neurons that possess the substance P receptor are required for the development of central sensitization. J Neurosci 22:9086-9098.

Klein T, Magerl W, Treede RD (2006) Perceptual correlate of nociceptive long-term potentiation (LTP) in humans shares the time course of earlyLTP. J Neurophysiol 96:3551-3555.

Klose RJ, Bird AP (2004) MeCP2 behaves as an elongated monomer that does not stably associate with the Sin3a chromatin remodeling complex. J Biol Chem 279:46490-46496.
Lee CT, Tyan SW, Ma YL, Tsai MC, Yang YC, Lee EH (2006) Serum- and glucocorticoid-inducible kinase (SGK) is a target of the MAPK/ERK signaling pathway that mediates memory formation in rats. Eur J Neurosci 23:1311-1320.

Levenson JM, Choi S, Lee SY, Cao YA, Ahn HJ, Worley KC, Pizzi M, Liou HC, Sweatt JD (2004) A bioinformatics analysis of memory consolidation reveals involvement of the transcription factor c-rel. J Neurosci 24:3933-3943.

Ma YL, Tsai MC, Hsu WL, Lee EH (2006) SGK protein kinase facilitates the expression of long-term potentiation in hippocampal neurons. Learn Mem 13:114-118.

Martin KC, Barad M, Kandel ER (2000) Local protein synthesis and its role in synapse-specific plasticity. Curr Opin Neurobiol 10:587-592.

Martinowich K, Hattori D, Wu H, Fouse S, He F, Hu Y, Fan G, Sun YE (2003) DNA methylation-related chromatin remodeling in activity-dependent BDNF gene regulation. Science 302:890-893.

McClung CA, Nestler EJ, Zachariou V (2005) Regulation of gene expression by chronic morphine and morphine withdrawal in the locus ceruleus and ventral tegmental area. J Neurosci 25:6005-6015.

Millan MJ (1999) The induction of pain: an integrative review. Prog Neurobiol 57:1-164.

Millan MJ, Czlonkowski A, Morris B, Stein C, Arendt R, Huber A, Hollt V, Herz A (1988) Inflammation of the hind limb as a model of unilateral, localized pain: influence on multiple opioid systems in the spinal cord of the rat. Pain 35:299-312.

Moretti P, Levenson JM, Battaglia F, Atkinson R, Teague R, Antalffy B, Armstrong D, Arancio O, Sweatt JD, Zoghbi HY (2006) Learning and memory and synaptic plasticity are impaired in a mouse model of Rett syndrome. J Neurosci 26:319-327.

Nan X, Cross S, Bird A (1998a) Gene silencing by methyl-CpG-binding proteins. Novartis Found Symp 214:6-16.

Nan X, Ng HH, Johnson CA, Laherty CD, Turner BM, Eisenman RN, Bird A (1998b) Transcriptional repression by the methyl-CpG-binding protein MeCP2 involves a histone deacetylase complex. Nature 393:386-389.

Neugebauer V, Schaible HG, Weiretter F, Freudenberger U (1994) The involvement of substance $\mathrm{P}$ and neurokinin- 1 receptors in the responses of rat dorsal horn neurons to noxious but not to innocuous mechanical stimuli applied to the knee joint. Brain Res 666:207-215.

Nichols ML, Allen BJ, Rogers SD, Ghilardi JR, Honore P, Luger NM, Finke MP, Li J, Lappi DA, Simone DA, Mantyh PW (1999) Transmission of chronic nociception by spinal neurons expressing the substance $\mathrm{P}$ receptor. Science 286:1558-1561.

Nuber UA, Kriaucionis S, Roloff TC, Guy J, Selfridge J, Steinhoff C, Schulz R, Lipkowitz B, Ropers HH, Holmes MC, Bird A (2005) Up-regulation of glucocorticoid-regulated genes in a mouse model of Rett syndrome. Hum Mol Genet 14:2247-2256.

Okabe S, Kim HD, Miwa A, Kuriu T, Okado H (1999) Continual remodeling of postsynaptic density and its regulation by synaptic activity. Nat Neurosci 2:804-811.

Paxinos G, Watson C, Pennisi M, Topple A (1985) Bregma, lambda and the interaural midpoint in stereotaxic surgery with rats of different sex, strain and weight. J Neurosci Methods 13:139-143.

Pittenger C, Kandel E (1998) A genetic switch for long-term memory. C R Acad Sci III 321:91-96.

Rygh LJ, Suzuki R, Rahman W, Wong Y, Vonsy JL, Sandhu H, Webber M, Hunt S, Dickenson AH (2006) Local and descending circuits regulate long-term potentiation and zif268 expression in spinal neurons. Eur J Neurosci 24:761-772.

Samaco RC, Hogart A, LaSalle JM (2005) Epigenetic overlap in autismspectrum neurodevelopmental disorders: MECP2 deficiency causes reduced expression of UBE3A and GABRB3. Hum Mol Genet 14:483-492.

Smyth GK (2004) Linear models and empirical bayes methods for assessing differential expression in microarray experiments. Stat Appl Genet Mol Biol 3:3.

Storkson RV, Kjorsvik A, Tjolsen A, Hole K (1996) Lumbar catheterization of the spinal subarachnoid space in the rat. J Neurosci Methods 65:167-172.

Suzuki M, Yamada T, Kihara-Negishi F, Sakurai T, Oikawa T (2003) Direct association between PU. 1 and MeCP2 that recruits mSin3A-HDAC complex for PU. 1-mediated transcriptional repression. Oncogene 22:8688-8698.

Suzuki R, Morcuende S, Webber M, Hunt SP, Dickenson AH (2002) Super- 
ficial NK1-expressing neurons control spinal excitability through activation of descending pathways. Nat Neurosci 5:1319-1326.

Tao F, Tao YX, Gonzalez JA, Fang M, Mao P, Johns RA (2001) Knockdown of PSD-95/SAP90 delays the development of neuropathic pain in rats. NeuroReport 12:3251-3255.

Tao YX, Huang YZ, Mei L, Johns RA (2000) Expression of PSD-95/SAP90 is critical for $N$-methyl-D-aspartate receptor-mediated thermal hyperalgesia in the spinal cord. Neuroscience 98:201-206.

Todd AJ (2002) Anatomy of primary afferents and projection neurons in the rat spinal dorsal horn with particular emphasis on substance $P$ and the neurokinin 1 receptor. Exp Physiol 87:245-249.

Todd AJ, Puskar Z, Spike RC, Hughes C, Watt C, Forrest L (2002) Projection neurons in lamina I of rat spinal cord with the neurokinin 1 receptor are selectively innervated by substance p-containing afferents and respond to noxious stimulation. J Neurosci 22:4103-4113.

Torsney C, MacDermott AB (2006) Disinhibition opens the gate to pathological pain signaling in superficial neurokinin 1 receptor-expressing neurons in rat spinal cord. J Neurosci 26:1833-1843.

Tsai KJ, Chen SK, Ma YL, Hsu WL, Lee EH (2002) sgk, a primary glucocorticoid-induced gene, facilitates memory consolidation of spatial learning in rats. Proc Natl Acad Sci USA 99:3990-3995.

von Hertzen LS, Giese KP (2005) Memory reconsolidation engages only a subset of immediate-early genes induced during consolidation. J Neurosci 25:1935-1942.

Wang Z, Gardell LR, Ossipov MH, Vanderah TW, Brennan MB, Hochgeschwender U, Hruby VJ, Malan Jr TP, Lai J, Porreca F (2001) Pronocicep- tive actions of dynorphin maintain chronic neuropathic pain. J Neurosci 21:1779-1786.

Weihe E, Millan MJ, Hollt V, Nohr D, Herz A (1989) Induction of the gene encoding pro-dynorphin by experimentally induced arthritis enhances staining for dynorphin in the spinal cord of rats. Neuroscience 31:77-95.

Westberry JM, Sadosky PW, Hubler TR, Gross KL, Scammell JG (2006) Glucocorticoid resistance in squirrel monkeys results from a combination of a transcriptionally incompetent glucocorticoid receptor and overexpression of the glucocorticoid receptor co-chaperone FKBP51. J Steroid Biochem Mol Biol 100:34-41.

Wisden W, Errington ML, Williams S, Dunnett SB, Waters C, Hitchcock D, Evan G, Bliss TV, Hunt SP (1990) Differential expression of immediate early genes in the hippocampus and spinal cord. Neuron 4:603-614.

Wochnik GM, Ruegg J, Abel GA, Schmidt U, Holsboer F, Rein T (2005) FK506-binding proteins 51 and 52 differentially regulate dynein interaction and nuclear translocation of the glucocorticoid receptor in mammalian cells. J Biol Chem 280:4609-4616.

Woolf CJ (1983) Evidence for a central component of post-injury pain hypersensitivity. Nature 306:686-688.

Zhang RX, Lao L, Qiao JT, Malsnee K, Ruda MA (2004a) Endogenous and exogenous glucocorticoid suppresses up-regulation of preprodynorphin mRNA and hyperalgesia in rats with peripheral inflammation. Neurosci Lett 359:85-88.

Zhang RX, Lao L, Qiao JT, Ruda MA (2004b) Effects of aging on hyperalgesia and spinal dynorphin expression in rats with peripheral inflammation. Brain Res 999:135-141. 